\title{
Pregnancy Complications and Perinatal Outcomes of Women with Hemoglobinopathies
}

Eliny Aparecida Vargas Machado Salazar1, Maria Lúcia Ivo1, Sandra Luzinete Félix de Freitas", Maria Stella Figueiredo ${ }^{2}$, Maria Auxiliadora de Souza Gerk ${ }^{1}$, Cristina Brandt Nunes ${ }^{1}$, Berenice Assumpção Kikuchi', Elenir Rose Jardim Cury Pontes ${ }^{1}$, Ernesto Antonio Figueiró-Filho' ${ }^{1}$, Thais Priscila Biassi ${ }^{2}$, Isabelle Campos de Azevedo ${ }^{3}$, Rita de Cássia Lira da Silva ${ }^{3}$, Marcos Antonio Ferreira Júnior ${ }^{3}$

\section{Abstract}

Objective: To estimate the prevalence of gestational complications and perinatal outcomes in women with and without hemoglobinopathies.

Method: This is a cross-sectional study with a quantitative approach, performed from 110 medical records of pregnant women who underwent prenatal, childbirth, postpartum and perinatal care in a gynecology and obstetrics service of the University Hospital at the Federal University of Mato Grosso do Sul, Brazil, between 2010 and 2011.

Results: Gestational complications in women with and without hemoglobinopathies in the variables: obstetric (preterm labor, preeclampsia, ruptured membranes for more than six hours (17.06 times; 12.19 times; 4.27 times respectively); clinical: urinary tract infection, heart failure, severe anemia (2.97 times; 12.6 times; 9.75 times, respectively), and perinatal: cesarean delivery, neonatal infection; the newborn in the neonatal intensive care unit; fetal death, stillbirth (1.57 times; 39.00 times; 12.19 times; 12.9 times; 9.75 times; respectively) were higher in the presence of hemoglobinopathies.

Conclusion: The pregnancy outcomes of women with hemoglobinopathies, perinatal and their newborns showed a higher prevalence of complications than women without this change.
1 Federal University of Mato Grosso do Sul, Campo Grande/MS, Brazil.

2 Federal University of São Paulo, São Paulo/SP, Brazil.

3 Federal University of Rio Grande do Norte, Natal/RN, Brazil.

Contact information:

Marcos Antonio Ferreira Júnior.

Address: Federal University of Rio Grande do Norte, Health Science Center, Department of Nursing. Avenida Salgado Filho, S/N, Lagoa Nova, Natal/RN, Brasil. CEP: 59078-970.

Đmarcos_nurse@hotmail.com 


\section{Introduction}

In general, hemoglobinopathies are the most frequent monogenic diseases in the population. They are characterized by mutations or deletions in the genes encoding the alpha $(\alpha)$ and beta $(\beta)$ globin chains of the human hemoglobin molecule $(\mathrm{Hb})$ [1]. There are many hemoglobin variants described. However, the structural variants of hemoglobins $S$ and $\mathrm{C}(\mathrm{HbS}$ and $\mathrm{HbC}$ ) are the most common and clinically significant [2].

The $\mathrm{HbS}$ is a mutation in the $\beta$ globin gene, which is the substitution of glutamic acid (GAG) for valine (GTG) and it causes the hemoglobin physicochemical changes [3]. This structural change in $\mathrm{HbS}$ when in deoxygenation situations is organized in long polymers and change the morphology of the red blood cell, becoming elongated and sickle-shaped [4].

Sickle cell disease (SCD) is a generic term used to define a group of genetic diseases that have the predominance of $\mathrm{HbS}$ as a common characteristic [5], originated in Africa and due to the forced migration of slaves the disease was brought to the Americas [6].

The most severe form of SCD is the sickle cell anemia (HbSS) occurring more often in homozygous. SCD may also occur in double heterozygous when $\mathrm{HbS}$ is associated to other abnormal $\mathrm{Hb}$ able to generate $\mathrm{Hb}$ variants $(\mathrm{HbC}, \mathrm{HbD})$ or in the interaction with thalassemia [7].

$\mathrm{HbC}$ is also originated from a mutation in the $\beta$ globin gene. However, the GAG is replaced by lysine (AAG). In this case, there is also a change in hemoglobin structure making it more prone to crystallization [4]. In Brazil, double heterozygous for $\mathrm{HbS}$ and $\mathrm{HbC}$, hemoglobinopathy SC ( $\mathrm{HbSC}$ ), is the second demonstration in frequency after homozygous for $\mathrm{HbS}$.

According to data from the National Neonatal Screening Program (PNTN), there are about 200,000 carriers of sickle cell trait and 3,500 children with sickle cell disease or a sick child for every 1,000 live births are born each year in Brazil [8]. Thus, the prevalence of heterozygotes for $\mathrm{HbS}$ is higher in the North and Northeast (6\% to $10 \%$ ), while in the South and Southeast its prevalence is lower $(2 \%$ to $3 \%)$ [9].

In Brazil, a review literature study with original articles showed a heterogeneous distribution of the sickle cell disease and trait with a higher prevalence in the Northeast and lowest in the South, while pointing out the lack of publications in the northern region [10].

In the Central West region of Brazil, in the Mato Grosso do Sul state (MS), a study conducted from 2000 to 2005 showed genotypic changes in 2624 (1.38\%) newborns (NB). Among those with altered genotypes, 2,602 (99.16\%) newborns had sickle cell trait, and $16(0.61 \%)$ had the genotype Hb SS [11].

Another study carried out from 2006 to 2010 showed that with increased coverage of the screening program in 78 municipalities in the state of Mato Grosso do Sul, 3,011 (99.05\%) were HbAS, an asymptomatic form of the disease, $20(0.66 \%)$ were diagnosed with HbSS, eight $(0.26 \%)$ had results for $\mathrm{HbSC}$ and one NB (0.03\%) had HbSD association [12].

In a study of pregnant women in high-risk pregnancy clinic of the University Hospital of the Federal University of Mato Grosso do Sul (HU/UFMS), pointed out that of the 215 pregnant women analyzed, there were $17.7 \%$ with anemia and $4.7 \%$ detected hemoglobinopathies [13].

Before considered aspects as well as the existing gap in the literature on the subject, this study aimed to estimate the prevalence of gestational and perinatal outcomes of women with hemoglobinopathies.

\section{Method}

This is a cross-sectional study with a quantitative approach, performed from medical records of pregnant women who underwent prenatal, childbirth, postpartum and perinatal care in the Gynecology 
and Obstetrics Service of the University Hospital at the Federal University of Mato Grosso do Sul (HU/ UFMS), located in the city of Campo Grande/MS, from November 2010 to August 2011.

The data were collected from medical records of 110 pregnant women who divided into two groups: group 1 ( $n=32)$ with hemoglobinopathies (HbAS, hbAC, HbSS, $\beta$-thalassemia) and group $2(n=78)$ without hemoglobinopathies ( $\mathrm{HbAA})$.

The inclusion criteria for both groups were: diagnosis of hemoglobinopathies performed by hemoglobin electrophoresis; and the pre-natal, delivery and puerperal monitoring had been carried out at the University Hospital.

Records of women of Indian origin, under 18, who did not have complete prenatal care as outpatients studied, whose records did not report the results of hemoglobin electrophoresis test and data obstetric and perinatal outcome were excluded from the study.

An instrument with the clinical, obstetrical and perinatal variables was designed for data collection, objects of this study: a) clinical: Urinary Tract Infection (UTI), heart failure, severe anemia, and pneumonia. b) Obstetric: pre-term labor, membrane broken time more than 6 hours, preeclampsia, abnormal amniotic fluid, delayed intrauterine growth, two or more abortions in obstetric history, stillbirth in obstetric history and gestational diabetes mellitus. c) Perinatal: cesarean delivery, fetal death (defined as death of the product design, which occurred prior to complete expulsion or extraction from the mother, regardless of the time of pregnancy), miscarriage, stillbirth (originates from the stillbirth) [14], Apgar score at 5 minutes less than seven, low birth weight of infants (birth weight measured within the first 60 minutes less than 2,500g), a small newborn (NB) for its gestational age (SGA) (classification of newborns, according to their degree of nutritional status, according to Lubchenko curve, which measures the relationship between birth weight and gestational age, considered SGA) [15], neona- tal infection, infants in neonatal intensive care unit (NICU) and puerperal infection.

Statistical analysis was performed using the EpiInfo software version 3.4.3 and Biostat. The evaluation of the association between the presence or absence of hemoglobinopathies and obstetric, clinical and perinatal variables of pregnancies was performed using the chi-square test or Fisher's exact test when one of the contingency table cells had a lower frequency than five. In both tests used, the significance level of 5\% was adopted.

This study met the national and international standards of ethics in research involving human beings, approved in its ethical and methodological aspects by the Ethics Committee on Research of the Federal University of Mato Grosso do Sul, according to the National Council of Health $\mathrm{N}^{\circ} 466 / 2012$ [16], under Opinion N 1,781/2010.

\section{Results}

There were 110 medical records analyzed of pregnant women with and without hemoglobinopathies assisted at the Gynaecology and Obstetrics Clinic of the HU/UFMS to research clinical, obstetric and perinatal complications in pregnancies.

In the obstetric variables, the preterm labor, preeclampsia and membrane broken time higher than six hours were $(17.06,12.19,4.27$ respectively) times more prevalent in women of pregnancies with hemoglobinopathies (Table 1).

Table 1. Relationship between obstetric variables and the presence of hemoglobinopathies in pregnancies analyzed in the period from 2010 to 2011. Campo Grande/MS, Brazil, $2016(n=110)$.

\begin{tabular}{|c|c|c|c|c|c|c|}
\hline \multirow{3}{*}{$\begin{array}{l}\text { Obstetric } \\
\text { variables }\end{array}$} & \multicolumn{4}{|c|}{ Hemoglobinopathies } & \multirow{3}{*}{$\begin{array}{c}\mathrm{PR}^{1} \\
(\mathrm{Cl} 95 \%)\end{array}$} & \multirow{3}{*}{$p^{2}$} \\
\hline & \multicolumn{2}{|c|}{$\begin{array}{l}\text { Present } \\
(n=32)\end{array}$} & \multicolumn{2}{|c|}{$\begin{array}{c}\text { Absent } \\
(n=78)\end{array}$} & & \\
\hline & $n$ & $\%$ & $n$ & $\%$ & & \\
\hline $\begin{array}{l}\text { Preterm } \\
\text { labor }\end{array}$ & 7 & 21.9 & 1 & 1.3 & $\begin{array}{c}17.06 \\
(2.19-133.14)\end{array}$ & 0.001 \\
\hline
\end{tabular}




\begin{tabular}{|c|c|c|c|c|c|c|}
\hline \multirow{3}{*}{$\begin{array}{l}\text { Obstetric } \\
\text { variables }\end{array}$} & \multicolumn{4}{|c|}{ Hemoglobinopathies } & \multirow{3}{*}{$\begin{array}{c}\mathrm{PR}^{1} \\
\text { (CI 95\%) }\end{array}$} & \multirow{3}{*}{$p^{2}$} \\
\hline & \multicolumn{2}{|c|}{$\begin{array}{l}\text { Present } \\
(n=32)\end{array}$} & \multicolumn{2}{|c|}{$\begin{array}{l}\text { Absent } \\
(n=78)\end{array}$} & & \\
\hline & $n$ & $\%$ & $n$ & $\%$ & & \\
\hline $\begin{array}{l}\text { Membrane } \\
\text { broken for } \\
\text { more than } 6 \\
\text { hours }\end{array}$ & 7 & 21.9 & 4 & 5.1 & $\begin{array}{c}4.27 \\
(1.34-13.57)\end{array}$ & 0.013 \\
\hline Pre-eclampsia & 5 & 15.6 & 1 & 1.3 & $\begin{array}{c}12.19 \\
(1.48-100.25)\end{array}$ & 0.008 \\
\hline $\begin{array}{l}\text { Changes in } \\
\text { AF }\end{array}$ & 4 & 12.5 & 7 & 9.0 & $\begin{array}{c}1.39 \\
(0.44-4.43)\end{array}$ & 0.727 \\
\hline IUGR & 3 & 9.4 & 8 & 10.3 & $\begin{array}{c}0.91 \\
(0.26-3.23)\end{array}$ & 1.000 \\
\hline $\begin{array}{l}\text { Two or more } \\
\text { abortions in } \\
\text { the OP }\end{array}$ & 3 & 9.4 & 5 & 6.4 & $\begin{array}{c}1.46 \\
(0.37-5.76)\end{array}$ & 0.689 \\
\hline $\begin{array}{l}\text { Stillbirth } \\
\text { in OP }\end{array}$ & 1 & 3.1 & 1 & 1.3 & $\begin{array}{c}2.44 \\
(0.16-37.79)\end{array}$ & 0.499 \\
\hline $\begin{array}{l}\text { Gestational } \\
\text { Diabetes } \\
\text { mellitus }\end{array}$ & 7 & 21.9 & 9 & 11.5 & $\begin{array}{c}1.90 \\
(0.77-4.65)\end{array}$ & 0.232 \\
\hline
\end{tabular}

The clinical variables of urinary tract infection, heart failure, severe anemia were $(2.97,12.6,9.75$ respectively) times more prevalent in pregnancies of women with hemoglobinopathies (Table 2).

Table 2. Relationship between clinical variables and the presence of hemoglobinopathies in pregnancies analyzed in the period from 2010 to 2011. Campo Grande/MS, Brazil, $2016(n=110)$.

\begin{tabular}{|c|c|c|c|c|c|c|}
\hline \multirow{3}{*}{$\begin{array}{l}\text { Clinical } \\
\text { variables }\end{array}$} & \multicolumn{4}{|c|}{ Hemoglobinopathies } & \multirow{3}{*}{$\begin{array}{c}P^{1} \\
\text { (CI 95\%) }\end{array}$} & \multirow{3}{*}{$p^{2}$} \\
\hline & \multicolumn{2}{|c|}{$\begin{array}{l}\text { Present } \\
(n=32)\end{array}$} & \multicolumn{2}{|c|}{$\begin{array}{l}\text { Absent } \\
(n=78)\end{array}$} & & \\
\hline & $\mathrm{n}$ & $\%$ & $n$ & $\%$ & & \\
\hline $\begin{array}{l}\text { Urinary tract } \\
\text { infection }\end{array}$ & 21 & 65.6 & 11 & 14.1 & $\begin{array}{c}2.97 \\
(1.60-5.53)\end{array}$ & $0.001^{2}$ \\
\hline $\begin{array}{l}\text { Heart } \\
\text { failure }\end{array}$ & 5 & 15.6 & 1 & 1.3 & $\begin{array}{c}12.19 \\
(1.48-100.25)\end{array}$ & $0.008^{3}$ \\
\hline $\begin{array}{l}\text { Severe } \\
\text { anemia }\end{array}$ & 4 & 12.5 & 1 & 1.3 & $\begin{array}{c}9.75 \\
(1.13-83.90)\end{array}$ & $0.025^{2}$ \\
\hline Pneumonia & 4 & 12.5 & - & - & - & $0.006^{2}$ \\
\hline
\end{tabular}

Perinatal variables of Cesarean childbirth, NB in the NICU; Neonatal Infection, Fetal death are (1.57; 12.19; 39.00; 12.19 respectively) times more prevalent in pregnancies of women with hemoglobinopathies (Table 3).

Table 3. Relationship between perinatal variables and the presence of hemoglobinopathies in pregnancies analyzed in the period from 2010 to 2011. Campo Grande/MS, Brazil, $2016(n=110)$.

\begin{tabular}{|c|c|c|c|c|c|c|}
\hline \multirow{3}{*}{$\begin{array}{l}\text { Perinatal } \\
\text { variables }\end{array}$} & \multicolumn{4}{|c|}{ Hemoglobinopathies } & \multirow{3}{*}{$\begin{array}{c}\mathrm{PR}^{1} \\
\text { (CI 95\%) }\end{array}$} & \multirow{3}{*}{$p$} \\
\hline & \multicolumn{2}{|c|}{$\begin{array}{l}\text { Present } \\
(n=32)\end{array}$} & \multicolumn{2}{|c|}{$\begin{array}{l}\text { Absent } \\
(n=78)\end{array}$} & & \\
\hline & $n$ & $\%$ & $n$ & $\%$ & & \\
\hline $\begin{array}{l}\text { Cesarean } \\
\text { delivery }\end{array}$ & 20 & 62.5 & 31 & 39.7 & $\begin{array}{c}1.57 \\
(1.07-2.31)\end{array}$ & $0.030^{2}$ \\
\hline Fetus death & 5 & 15.6 & 1 & 1.3 & $\begin{array}{c}12.19 \\
(1.48-100.25)\end{array}$ & $0.008^{3}$ \\
\hline Abortion & 9 & 28.1 & 18 & 23.1 & $\begin{array}{c}1.22 \\
(0.61-2.42)\end{array}$ & $0.576^{2}$ \\
\hline Stillbirth & 4 & 12.5 & 1 & 1.3 & $\begin{array}{c}9.75 \\
(1.13-83.90)\end{array}$ & $0.025^{3}$ \\
\hline $\begin{array}{l}\text { Apgar of } 5^{1} \\
\min <7\end{array}$ & 2 & 6.3 & 1 & 1.3 & $\begin{array}{c}4.88 \\
(0.46-51.89)\end{array}$ & $0.202^{3}$ \\
\hline $\begin{array}{l}\text { NB with } \\
\text { weight } \\
<2.500 \mathrm{~g}\end{array}$ & 5 & 15.6 & 15 & 19.2 & $\begin{array}{c}0.81 \\
(0.32-2.05)\end{array}$ & $0.656^{2}$ \\
\hline NB SGA & 1 & 3.1 & - & - & - & $0.291^{3}$ \\
\hline $\begin{array}{l}\text { Neonatal } \\
\text { infection }\end{array}$ & 16 & 50.0 & 1 & 1.3 & $\begin{array}{c}39.00 \\
(5.40-281.90)\end{array}$ & $0.001^{3}$ \\
\hline NB in NICU & 5 & 15.6 & 1 & 1.3 & $\begin{array}{c}12.19 \\
(1.48-100.25)\end{array}$ & $0.008^{3}$ \\
\hline $\begin{array}{l}\text { Infecção } \\
\text { puerperal }\end{array}$ & 2 & 6.3 & - & - & - & $0.083^{3}$ \\
\hline
\end{tabular}

1: PR, 2: Chi-square Test, 3: Fisher Exact Test. NB: newborn, NB SGA: Newborn in Small for Gestational Age, RN in NICU: Newborn in the Neonatal Intensive Care Unit.

\section{Discussion}

The sickle cell disease can influence the course of pregnancy since in 50\% of pregnancies there are infections and the systems more affected there are the respiratory and urinary [17]. In a study developed in Jamaica with pregnant women with sickle 
cell anemia, the researchers found that $57 \%$ of pregnancies progressed without complications [18]. For these reasons, preventive actions involving early diagnosis are necessary to minimize injuries in this segment of the population $[19,20]$.

In this study, the preterm labor was 17.06 more prevalent among women with pregnancies with hemoglobinopathies compared to those without hemoglobinopathies. These findings corroborated the studies in Cuba and Jamaica, which received high frequency of preterm births [18, 21, 22].

Thus, in this study, the prevalence of prolonged rupture of membranes was four times higher, and preeclampsia was 12 times higher in pregnancies of women with hemoglobinopathies compared with those without it. Other studies have found high rates of preeclampsia among women with sickle cell disease [23, 24].

It was also found that UTI was twice as prevalent among women with pregnancies with hemoglobinopathies compared with those without it. Similar results have been reported in the literature $[5,22]$. It should be emphasized that in sickle cell disease there is an increased risk for urinary tract infections. When they occur during pregnancy, they may contribute to other complications such as miscarriage or preterm labor [21]. In a study conducted in Tanzania with 149 pregnant women, there was an excess risk of maternal deaths by sickle cell disease compared with those who had not. The infections were the most common cause of $82 \%$ and $32 \%$ without the disease [25].

Severe anemia was 9.75 times more prevalent in women with pregnancies with hemoglobinopathies compared to those without it. The lower survival of red blood cells is the main cause of anemia in patients with sickle cell disease, which stems from hemolytic anemia with increased indirect bilirubin, erythroid hyperplasia of the bone marrow and elevated reticulocyte [4].

As for perinatal variables, it was found that cesarean section was more frequent among women with hemoglobinopathies with 1.57 times more prevalent in pregnancies of women with hemoglobinopathies when compared with those who had not. A fact discussed in a cohort study, in which the proportion of caesarean sections was increased both in the group of women with sickle cell disease and the group of carriers of sickle cell trait, with no significant difference between them [22].

The fetal death was approximately 15.6 times more prevalent in women in pregnancies with hemoglobinopathies compared to those without it. Research developed in a high-risk pregnancy service of a university tertiary referral hospital in southeastern Brazil showed that $12 \%$ of stillbirths occurred in women with sickle cell disease and $25 \%$ of them occurred due to severe placental insufficiency [22].

This study showed that the prevalence of neonatal infection was 39.6 times more prevalent among newborns of women with hemoglobinopathies. There was a gap in the literature on neonatal infection and perinatal outcome in newborns of these women. However, prematurity situations, hospitalization in the NICU, low birth weight, intrauterine growth restriction associated with the mother's complications, especially preterm rupture of amniotic membranes and UTI, are factors that can increase the risk of infection to these infants [21, 22].

Studies show that pregnant women with hemoglobinopathies being more subject to various complications, such as infections, preeclampsia [6, 22], worsening anemia, worsening of bone lesions and retinopathy [22] and miscarriages. [4] Complications that affect the fetus or newborns in these cases are delayed intrauterine growth, low birth weight, prematurity and stillbirth [5, 22].

The prevalence in the Neonatal Intensive Care Unit was 12.19 times higher among newborns to women with hemoglobinopathies compared to the others. Although prematurity is prevalent in this disease, it cannot be considered the only factor that may cause the newborn to the Neonatal Intensive Care Unit [21, 22]. 
In this study, there was no association observed between the presence of hemoglobinopathies with the variables "two or more abortions in obstetric past," "stillbirth in obstetrical past," "delayed intrauterine growth," "Gestational Diabetes Mellitus" and "amniotic fluid change." A study conducted at the University Hospital of Southeastern Brazil, tertiary, was also no difference found in the occurrence of gestational diabetes when there was a comparison with sickle cell disease and pregnant women with sickle cell trait. However, the delay in intrauterine growth was significantly more frequent in the group with sickle cell disease [22].

In a systematic review of maternal and perinatal outcomes of pregnant women with sickle cell disease it was concluded that the risks are higher for pregnant women with sickle cell anemia - HbSS, and in low-income countries they are more susceptible to morbidity and mortality, in which access antenatal care with specialized multidisciplinary team are not properly systemized and implemented [23].

The limiting factors of this study were the presence of some characteristics complications of hemoglobinopathies, as the painful crises. Because this complication is not part of the clinical picture of pregnancies of women without hemoglobinopathies, it was decided not to examine them to avoid bias.

\section{Conclusion}

It was observed that women with hemoglobinopathies pregnancies have a higher prevalence of higher obstetric, clinical and perinatal complications compared to those without this condition. The complications identified were preterm birth, preterm labor, preeclampsia, UTI. In newborns of pregnant women with sickle cell disease, there was a prevalence of newborns in the NICU and Neonatal deaths.

The knowledge of the complications that can affect women with hemoglobinopathies during preg- nancy and puerperal period, and their newborns, enables the health professional for more effective assistance for prevention and early identification as well as the decision-making of such cases.

This study highlights the need for research to investigate neonatal infection of the newborn of pregnant women with sickle cell disease. It is necessary for health investments in Brazil to offer specialized support services to women with hemoglobinopathies so that they can exercise their sexual and reproductive rights without resulting in more risks to their health.

\section{References}

1. Naoum PC. Hemoglobinopatias e talassemias. São Paulo: Sarvier, 2004.

2. Almeida AM, Henthorn JS, Davies SC. Neonatal screening for haemoglobinopathies: the results of a 10-year programme in an English Health Region. Br J Haematol 2001;112(1):32-5.

3. Backes CE, Mallmann FG, Dassi T, Bazzo ML, Santos-Silva MC. Triagem neonatal como um problema de saúde pública. Rev Bras Hematol Hemoter 2005; 27(1): 43-7.

4. Zago MA, Pinto ACS. The pathophysiology of sickle cell disease: from the genetic mutation to multiorgan disfunction. Rev. bras. hematol. hemoter. 2007; 29(3): 207-14.

5. Zanettte AD. Pregnancy and contraception in sickle cell disease. 2007; 29(3): 309-12.

6. Frempong KO. Sickle cell disease in the United States of America and Africa. Hematology (Am Soc Hematol Educ Program). 1999: 64-71.

7. Bonini-Domingos CR. Diagnóstico Laboratorial nas doenças falciformes, in: Hematologia: um olhar sobre a doença falciforme. UFMS, 2013 p. 45-72.

8. Simões BP, Pieroni F, Barros GMN, Machado CL, Cançado RD, Salvino MA, et al. Brazilian Consensus Meeting on Stem Cell Transplantation: Hemoglobinopathies Committee. Rev. bras. hematol. hemoter. 2010; 32(Supl. 1): 46-53.

9. Cançado RD, Jesus JA. Sickle cell disease in Brazil. Rev. bras. hematol. hemoter. 2007; 29(3): 204-6

10. Lervolino LG, Baldin PEA, Picado SM, Calil KB, Viel AA, Campos LAF. Prevalence of sickle cell disease and sickle cell trait in national neonatal screening studies. Rev. bras. hematol. hemoter. 2011; 33(1): 49-54.

11. Holsbach DR, Ivo ML, Honer MR, Rigo L, Botelho CAO. Ocorrência de hemoglobina S no Estado de Mato Grosso do Sul, Brasil. J Bras Patol Med Lab. 2008; 44(4): 277-82. 
12. Ivo ML, Araujo OMR, Barbieri AR, Corrêa Filho RAC, Pontes ERJC, Botelho CAO. Scope and efficiency of the newborn screening program in identifying hemoglobin S. Rev. bras. hematol. hemoter. 2014; 36(1): 14-18.

13. Sakamoto TM, Ivo ML, Brum MAR, PontesERJC, Bonini-Domingos $C R$, Ferreira Júnior MA. Anemia and hemoglobinopathies in pregnant women attended in a public hospital. J Nurs UFPE on line. 2012; 6(7): 1576-81.

14. World Health Organization. International statistical classification of diseases and related health problems. 10th revision, edition 2010. 3 v. Geneva: WHO Press; 2010.

15. Senesi LG, Tristão EG, Andrade RP, Krajden ML, Oliveira Junior FC, Nascimento DJ. Neonatal Morbity and Mortality Related to Pregnant Women at the Age of 35 and Older, according to Parity. RBGO. 2004; 26(6): 477-82.

16. Brasil. Resolução n. 466, de 12 de dezembro de 2012. Dispõe sobre diretrizes e normas regulamentadoras de pesquisas envolvendo seres humanos. Diário Oficial da República Federativa do Brasil; 2012. Seção 1. p. 59-62.

17. Leborgne-Samuel $Y$, Janky E, Venditelli F, Salin J, Daijardin J-B, Couchy B, et al. Drépanocytose et grossesse:revue de 68 observations en Guadeloupe. J Gynecol Obstet Biol Reprod. 2000; 29(1): 86-93.

18. Serjeant GR, Loy LL, Crowther MB, Hambleton IR, Thame M. Outcome of pregnancy in homozygous sickle cell disease. Obstet Gynecol. 2004; 103(6): 1278-85.

19. Viana-Baracioli LMS, Bonini-Domingos CR, Pagliusi RA, Naoum PC. Prevenção de hemoglobinopatias a partir do estudo em gestantes. Rev. bras. hematol. hemoter. 2001; 23(1): 31-9.

20. Oñate MF, Bess MÊS, Brown YC. Análisis del trabajo en gestantes con hemoglobinopatías en el municipio Santiago de Cuba. Rev Cubana Enfermer. 1999; 15(3): 174-8.

21. Serjeant GR, Hambleton I, Thame M. Fecundity and pregnancy outcome in a cohort with sickle cell-haemoglobin $C$ disease followed from birth. BJOG. 2005; 112(9): 1308-14.
22. Nomura RMY, Igai AMK, Tosta K, Fonseca GHH, Gualandro SFM, Zugaib M. Maternal and perinatal outcomes in pregnancies complicated by sickle cell diseases. Rev Bras Ginecol Obstet. 2010; 32(8): 405-11.

23. Oteng-Ntim E, Meeks D, Seed PT, Webster L, Howard J, Doyle $P$, Chappell LC. Adverse maternal and perinatal outcomes in pregnant women with sickle cell disease: systematic review and meta-analysis. Blood. 2015; 125(21): 3316-25.

24. Wilson NO, Ceesay FK, Hibbert JM, Driss A, Obed SA, Adjei $A A$, et al. Pregnancy Outcomes among Patients with Sickle Cell Disease at Korle-Bu Teaching Hospital, Accra, Ghana: Retrospective Cohort Study. Am J Trop Med Hyg. 2012; 86(6): 936-42.

25. Mugannyzi PS, Kidanto H. Sickle cell disease in pregnancy: trend and pregnancy outcome at a tertiary hospital in Tanzania. PLoS One. 2013; 8(2)
Publish in International Archives of Medicine

International Archives of Medicine is an open access journal publishing articles encompassing all aspects of medical science and clinical practice. IAM is considered a megajournal with independent sections on all areas of medicine. IAM is a really international journal with authors and board members from all around the world. The journal is widely indexed and classified Q2 in category Medicine. 